\title{
Exploring the Limits of Crop Productivity: Beyond the Limits of Tipburn in Lettuce
}

\author{
Jonathan M. Frantz ${ }^{1}$ and Glen Ritchie ${ }^{2}$ \\ Crop Physiology Laboratory, Department of Plants, Soils, and Biometeorology, Utah State University, \\ Logan, UT 84322-4820
}

\begin{abstract}
Nilton N. Cometti ${ }^{3}$
Departmento de Solos, Instituto de Agronomia, UFRRJ, BR 465, km 07, 23850-000, Seropédica, RJ, Brasil

Justin Robinson and Bruce Bugbee

Crop Physiology Laboratory, Department of Plants, Soils, and Biometeorology, Utah State University, Logan, UT 84322-4820
\end{abstract}

\begin{abstract}
AdDITIONAL INDEX wORDS. crop optimization, determinants of growth, Ca deficiency, quantum yield, radiation capture, carbon use efficiency

ABstract. The productivity of lettuce in a combination of high light, high temperature, and elevated $\mathrm{CO}_{2}$ has not been commonly studied because rapid growth usually causes a calcium deficiency in meristems called tipburn, which greatly reduces quality and marketability. We eliminated tipburn by blowing air directly onto the meristem, which allowed us to increase the photosynthetic photon flux $(P P F)$ to $1000 \mu \mathrm{mol} \cdot \mathrm{m}^{-2 \cdot} \cdot \mathrm{s}^{-1}\left(57.6 \mathrm{~mol} \cdot \mathrm{m}^{-2 \cdot} \mathrm{d}^{-1}\right)$; two to three times higher than normally used for lettuce. Eliminating tipburn doubled edible yield at the highest $P P F$ level. In addition to high $P P F, \mathrm{CO}_{2}$ was elevated to $1200 \mu \mathrm{mol} \cdot \mathrm{m}^{-2} \cdot \mathrm{mol}^{-1}$, which increased the temperature optimum from 25 to $30{ }^{\circ} \mathrm{C}$. The higher temperature increased leaf expansion rate, which improved radiation capture and more than doubled yield. Photosynthetic efficiency, measured as canopy quantum yield in a whole-plant gas exchange system, steadily increased up to the highest temperature of $32{ }^{\circ} \mathrm{C}$ in high $\mathrm{CO}_{2}$. The highest productivity was $19 \mathrm{~g} \cdot \mathrm{m}^{-2} \cdot \mathrm{d}^{-1}$ of dry biomass $\left(380 \mathrm{~g} \cdot \mathrm{d}^{-1}\right.$ fresh mass $)$ averaged over the 23 days the plants received light. Without the limitation of tipburn, the combination of high PPF, high temperature, and elevated $\mathrm{CO}_{2}$ resulted in a 4 -fold increase in growth rate over productivity in conventional environments.
\end{abstract}

Horticulturists have long sought to maximize yield and quality of all crop plants. Pollan (2002) summarized the historical quest to attain high yield and quality of potato (Solanum tuberosum), apple (Malus pumila), tulip (Tulipa spp.), and marijuana (Cannabis sativa). Three physiological determinants govern biomass yield in all plants: radiation capture, quantum yield or quantum efficiency, and respiration or carbon use efficiency (Bugbee and Salisbury, 1988). These determinants can be individually measured to determine how closely they approach the theoretical maximum. Recent advances in instrumentation (e.g., digital photography and infrared gas analyzers) facilitate more precise measurements of each of these determinants.

Radiation capture is a critical component of productivity. Leaf expansion rate and leaf emergence rate are greatly influenced by temperature (Faust and Heins, 1994; Clifton-Brown and Jones, 1997) and provide the means to capture light as plants develop from seedlings. Temperature optimums vary widely among species. Cotton has a temperature optimum for leaf expansion of $\approx 31^{\circ} \mathrm{C}$ (Reddy

Received for publication 1 Aug. 2003. Accepted for publication 26 Nov. 2003. Approved by Utah Agricultural Experiment Station as journal paper no. 7547. This research was supported by the National Aeronautics and Space Administration Advanced Life Support Program, the National Aeronautics and Space Administration Graduate Student Research Program, and by the Utah Agricultural Experiment Station, Utah State University. We would like to thank Theodore W. Tibbitts, A.J. Both, and Raymond Wheeler for reviewing this manuscript and for their helpful discussion of experimental treatments and design.

${ }^{1}$ Current address is USDA-ARS-ATRU, University of Toledo, Mail Stop 604, 2801 W. Bancroft, Toledo, $\mathrm{OH}$ 43606. To whom reprint requests should be addressed; e-mail Jonathan.Frantz@utoledo.edu.

${ }^{2}$ Current address is College of Agricultural and Environmental Sciences, University of Georgia Coastal Plain Experiment Station, P.O. Box 748, Tifton, GA 31794.

${ }^{3}$ Current address is Escola Agrotécnica Federal de Colatina, BR 259-km 70-Cx Postal 256, Colatina, ES-CEP 29709-910 Brasil. et al., 1993), and broccoli has an optimum of only $21^{\circ} \mathrm{C}$ (Olesen and Grevsen, 1997). The temperature optimum for leaf expansion and radiation capture in lettuce is not well characterized.

Quantum yield is highly sensitive to temperature and $\mathrm{CO}_{2}$. Measurement of Rubisco in vitro and studies with single leaves indicate that the temperature optimum for photosynthesis in $\mathrm{C} 3$ species increases several degrees under elevated $\mathrm{CO}_{2}$ (Harley and Tenhunen, 1991; Long, 1991). Photorespiration is nearly eliminated by elevating $\mathrm{CO}_{2}$ above $1000 \mu \mathrm{mol} \cdot \mathrm{m}^{-2} \cdot \mathrm{s}^{-1}$, so electron transport becomes the rate limiting factor in $\mathrm{CO}_{2}$ fixation. Electron transport can increase up to 30 to $35^{\circ} \mathrm{C}$ (Farquhar et al., 1980). As a consequence, quantum yield significantly increases because of both reduced photorespiration and increased electron transport in high temperatures with elevated $\mathrm{CO}_{2}$.

Carbon use efficiency (CUE) is a measure of how well a plant incorporates newly fixed carbon into biomass. It is the ratio of carbon gain to total fixed carbon or daily integrated new photosynthesis to daily integrated gross photosynthesis $\left(\mathrm{P}_{\text {gross }}\right)$. Because CUE includes both respiration and photosynthesis rates, it may be sensitive to temperature, $P P F$, and $\mathrm{CO}_{2}$ concentration. CUE is not well characterized for plants, and little information exists for lettuce CUE in different environments.

The theoretical maximum productivity can be calculated, based on highest measured efficiency of each of the three component processes. Assuming 95\% absorption of the incident light (Monje and Bugbee, 1998), a quantum yield of $0.083 \mathrm{~mol}$ carbon per mol of photons (Lal and Edwards, 1995), and a carbon use efficiency of 0.8 (Amthor, 1989), the theoretical maximum productivity is 0.063 moles of carbon per mole of photosynthetic photons. If the biomass is $40 \%$ carbon, this results in $1.9 \mathrm{~g}$ of dry biomass per mole of photosynthetic photons. If the daily $P P F$ is $57.6 \mathrm{~mol} \cdot \mathrm{m}^{-2} \cdot \mathrm{d}^{-1}$ 
Table 1. Environmental conditions for the three studies. $\mathrm{CO}_{2}$ was elevated in all studies to $1200 \mu \mathrm{mol} \cdot \mathrm{m}^{-2} \cdot \mathrm{mol}^{-1}$. Light was provided by high-pressure sodium lamps with a 16-h photoperiod.

\begin{tabular}{|c|c|c|c|c|c|c|c|}
\hline $\begin{array}{l}\text { Study } \\
\text { no. }\end{array}$ & Treatment(s) & Root-zone & $\begin{array}{c}P P F \\
\left(\mu \mathrm{mol} \cdot \mathrm{m}^{-2} \cdot \mathrm{s}^{-1}\right)\end{array}$ & $\begin{array}{l}\text { Temp } \\
\left({ }^{\circ} \mathrm{C}\right) \\
\text { day/night }\end{array}$ & $\begin{array}{l}\text { Relative } \\
\text { humidity } \\
(\%)\end{array}$ & $\begin{array}{l}\text { Meristem } \\
\text { aeration }\end{array}$ & Cultivar(s) \\
\hline$\overline{1}$ & Temperature & $\begin{array}{l}\text { Solution } \\
\text { hydroponics }\end{array}$ & 600 & $\begin{array}{l}23 / 18,26 / 21, \\
29 / 24,32 / 27, \\
35 / 30\end{array}$ & $60-80$ & No & Grand Rapids \\
\hline 2 & Light, cultivar, aeration & Soilless media & 500 and 1000 & $30 / 25$ & 75 & Half of all canopies & $\begin{array}{l}\text { Buttercrunch, } \\
\text { Grand Rapids, } \\
\text { Tiber, } \\
\text { Waldmann's Green }\end{array}$ \\
\hline 3 & Cultivar, aeration & Soilless media & 1000 & $30 / 25$ & 75 & Half of all canopies & $\begin{array}{l}\text { Buttercrunch } \\
\text { Waldmann's Green }\end{array}$ \\
\hline
\end{tabular}

(1000 $\mu \mathrm{mol} \cdot \mathrm{m}^{-2} \cdot \mathrm{s}^{-1}$ for a 16 -h photoperiod), the productivity could be $109 \mathrm{~g} \cdot \mathrm{m}^{-2} \cdot \mathrm{d}^{-1}$. This would require a system that achieved a light absorption of $95 \%$ over the life cycle, and a maximum QY, even in high light. What typically occurs is an average from emergence to harvest of $50 \%$ absorption of incident light, a quantum yield of $\approx 0.04 \mathrm{~mol}$ carbon $/ \mathrm{mol}$ photons, and a carbon use efficiency of 0.6 for an average of $0.36 \mathrm{~g}$ dry biomass per square meter per day per mole of photosynthetic photons. There is opportunity to maximize each of the determinants of growth, but it is difficult to optimize all of them at the same time to obtain the highest possible growth rates. Unless an analysis is performed that examines each of the determinants of growth, breeders have little information as to what may be most limiting to productivity.

Lettuce is typically grown in low temperatures (daytime temperatures between 20 to $25^{\circ} \mathrm{C}$ ) and in low light (often the maximum is $\left.400 \mu \mathrm{mol} \cdot \mathrm{m}^{-2} \cdot \mathrm{s}^{-1}\right)($ Hammer et al., 1978, Swiader et al., 1992; Koontz and Prince, 1986; Jie and Kong, 1997). While adequate yields can be obtained in this environment, the main reason for these growth conditions is to minimize a calcium disorder called tipburn and improve quality (Saure, 1998). High growth rates of lettuce almost always result in tipburn. Tipburn occurs when laticifer cells burst due to weak cell walls or excessive turgor pressure within the laticifers (Tibbitts et al., 1985). Calcium, an important component of cell walls, is not phloem mobile, so most $\mathrm{Ca}^{2+}$ is supplied through the xylem and thus preferentially moves to tissues with high transpiration rates (Marchner, 1995). Lettuce meristems are located in the interior of older, more developed leaves, which reduces transpiration and $\mathrm{Ca}^{2+}$ supply (Barta and Tibbitts, 1986; Barta and Tibbitts, 1991; Barta and Tibbitts, 2000). Furthermore, meristems and late-forming leaves have low transpiration rates and poorly developed xylem to supply calcium (Barta, 1989). The faster the growth rate, the more calcium is needed and the rate and extent of tipburn increases. This same calcium deficiency occurs in rapidly expanding tissue in most crops, such as strawberry (Fragaria $\times$ ananassa) leaves, sugar beet (Beta vulgaris), cabbage (Brassica oleracea), and tomato (Lycopersicum esculentum) and apple fruit (Mostafa and Ulrich, 1976; Bradfield and Guttridge, 1984; Ho et al., 1993; Cubeta et al., 2000; Morard et al., 2000).

High light increases growth rates, which increases the need for $\mathrm{Ca}^{2+}$ in the meristem and increases tipburn. Several other environmental factors have been shown to increase tipburn. Low day-time humidity can increase tipburn because more water is disproportionately transpired through exposed leaves while the interior meristem is in a high-humidity environment (Collier and Wurr, 1981; Collier and Tibbitts, 1984). High humidity can increase tipburn by slowing transpiration in the meristem and thus reducing the flow of $\mathrm{Ca}^{2+}$ to the meristem. Low humidity at night may decrease plant turgor potential, and result in less $\mathrm{Ca}^{2+}$ being pushed to leaf tips and meristems by guttation. High salinity (or solution electrical conductivity) can also reduce night-time turgor and guttation (Feigin et al., 1991). $\mathrm{Ca}^{2+}$ uptake is inhibited by other cations, so increased levels of $\mathrm{NH}_{4}{ }^{+}$and $\mathrm{K}^{+}$typically reduce $\mathrm{Ca}^{2+}$ uptake (Marschner, 1995; Misaghi et al., 1981a; Rosen, 1990). Wind can reduce tipburn by reducing the vapor pressure deficit around a meristem thereby increasing transpiration of the meristem (Shibata et al., 1995). Finally, temperature can influence tipburn both through its effect on vapor pressure deficit around the meristem and effect on growth rate (Yanagi et al., 1983; Misaghi and Grogan, 1978).

Controlled environments offer a way to optimize all environmental parameters to achieve the full genetic yield potential. Paradoxically, an optimized environment with high light results in higher growth rates, so lettuce production in controlled environments is particularly sensitive to tipburn. Genetic selection has resulted in tipburn resistance in the field (Welsh et al., 1983; Ryder and Waycott, 1998), but these tipburn resistant cultivars have not been tested in controlled environments.

We optimized the environment for lettuce by blowing air on the meristems to eliminate tipburn, elevating $\mathrm{CO}_{2}$, increasing temperature, altering the $\mathrm{NH}_{4}{ }^{+}$and $\mathrm{K}^{+}$nutrient balance to increase calcium uptake, increasing the wind speed, and controlling humidity. These environmental and cultural changes allowed us to use high PPF levels to determine the potential productivity. Radiation capture, quantum yield, and carbon use efficiency were separately measured to determine the effect of elevated temperature on these three determinants of yield.

\section{Materials and Methods}

Three studies were performed (Table 1). $\mathrm{CO}_{2}$ was elevated to $1200 \mu \mathrm{mol} \cdot \mathrm{mol}^{-1}\left( \pm 2 \%\right.$, or $\left.\pm 24 \mu \mathrm{mol} \cdot \mathrm{mol}^{-1}\right)$ in all trials. $\mathrm{CO}_{2}$ was elevated to ensure that photosynthesis would be light- rather than $\mathrm{CO}_{2}$-limited and to reduce photorespiration (Long, 1991; Bugbee et al., 1994). Lettuce is usually grown under broad spectrum lamps such as cool white fluorescent and metal halide, which have $\approx 30 \%$ of their output as blue light (400 to $500 \mathrm{~nm}$ ). However, Dougher and Bugbee (2001) found that lettuce plants grown under high pressure sodium (HPS) lamps, which have only $6 \%$ blue light, had increased leaf expansion rate, increased radiation capture, and increased growth by $\approx 25 \%$ compared to metal halide lamps. High pressure sodium lamps were thus used in all trials. The photoperiod was 16-h. Side lighting of plant communities was reduced with reflective material that was raised daily to match the canopy height. $P P F$ was measured at the top of the canopy with a recently calibrated 


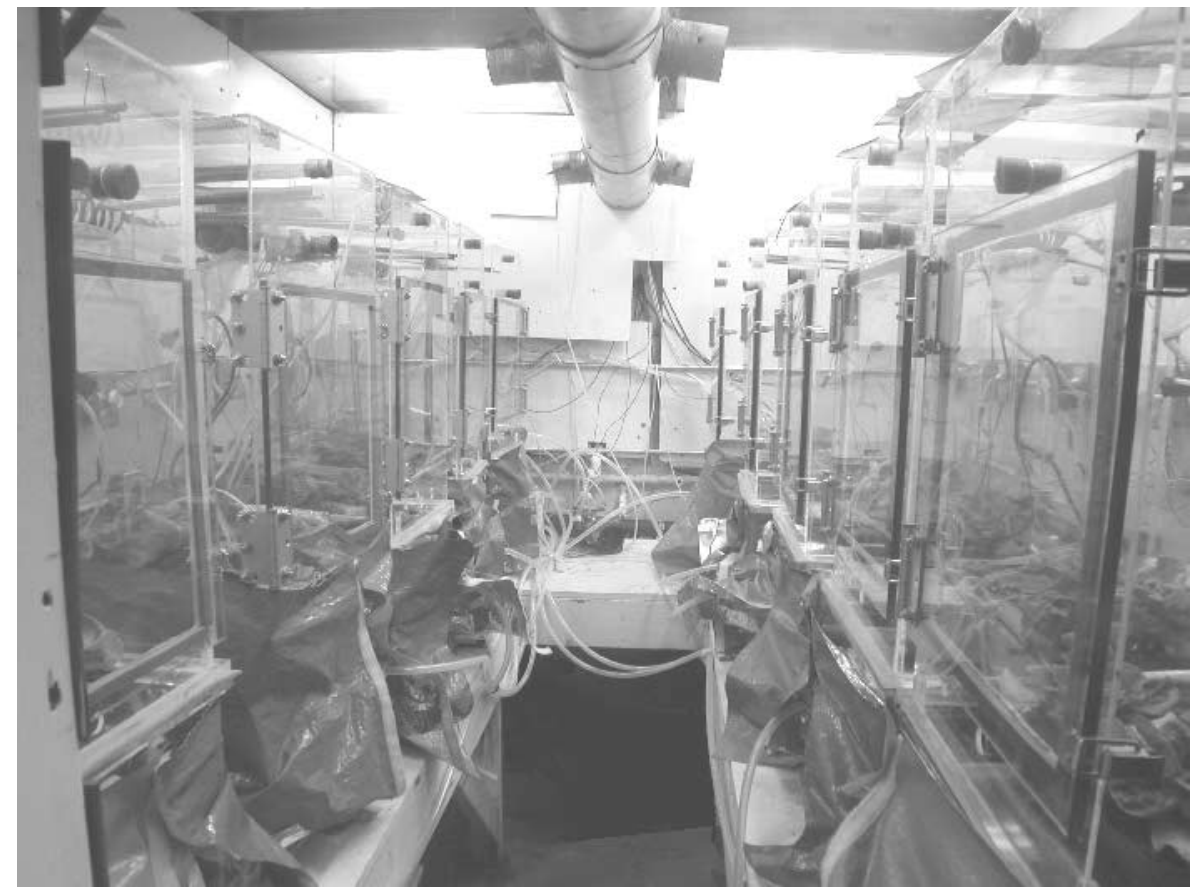

when ground cover reached $\approx 80 \%$ (Klassen et al.,2003). The combination of these two methods provided an accurate estimate of daily radiation capture. Canopy quantum yield $(C Q Y)$ was then calculated by the following equation: $C Q Y=$ $P_{\text {gross }} / P P F$ absorbed $=$ mol C fixed $/ \mathrm{mol}$ photon absorbed, where $P_{\text {gross }}$ is daily integrated gross photosynthesis $\left(\mathrm{mol} \cdot \mathrm{C}^{-2} \cdot \mathrm{m}^{-2} \cdot \mathrm{d}^{-1}\right)$ and $P P F$ absorbed is total daily photons absorbed (mol photons/d). $P_{\text {gross }}$ is a calculated term that incorporates both the net $\mathrm{C}$ fixed $\left(P_{n e t}\right)$ and the $\mathrm{C}$ that is simultaneously being respired. $P_{\text {gross }}$ can be calculated as $P_{\text {gross }}=P_{\text {net }}+R_{d}$.

Net photosynthesis $\left(P_{n e t}\right)$ and nighttime respiration $\left(R_{n}\right)$ were measured directly. Since daytime respiration $\left(R_{d}\right)$ can not be measured directly, $P_{\text {gross }}$ is calculated as the sum of $P_{\text {net }}$ and some percentage of nighttime respiration rate. $R_{d}$ may remain high due to higher carbohydrate content during the day (AzcónBieto and Osmond, 1983), or may be lower due to light-inhibition of respiration (Atkin et al., 2000; Sharp et al., 1984). We have taken the common approach for whole plants to as-

Fig. 1. The 10-chamber gas-exchange system used in Study 1. There are five chambers on each side of a walk-in growth chamber. Each chamber has a reflective skirt wrapped around the outside to minimize side lighting.

line quantum sensor with 54 sensors along a 45-cm length (model LQSV-ELEC; Apogee Instruments Inc., Logan, Utah) and adjusted weekly by adding neutral density shade cloth or reflectors.

Temperature STUdy (STUdy 1). Lettuce (Latuca sativa L. 'Grand Rapids') was germinated and transplanted after four days into 10 small chambers at a density of 106 plants $/ \mathrm{m}^{2}$. Five temperature treatments of $23 / 18,26 / 21,29 / 24,32 / 27,35 / 30{ }^{\circ} \mathrm{C}$ day/night were initiated upon transplanting and were controlled to within $\pm 0.2^{\circ} \mathrm{C}$ of setpoint. Treatments were arranged as a randomized complete block design, and analyzed using linear regression and ANOVA.

A 10-chamber open gas exchange system was used as described previously (Fig. 1; van Iersel and Bugbee, 2000). Each chamber is $0.5 \times 0.4 \times 0.9 \mathrm{~m}(\mathrm{~L} \times \mathrm{W} \times \mathrm{H})$ and fully enclosed a hydroponic tub. Rootzone temperature was maintained by activating flexible heat stripping wrapped around the outside of the hydroponic tubs. Hydroponic solution was aerated with the same $\mathrm{CO}_{2}$-enriched air as that used in the canopy. $\mathrm{CO}_{2}$ gas exchange of each of the 10 different whole canopies was monitored once every ten minutes. The $\mathrm{pH}$ of the hydroponic solution was maintained between 4 and 5 , which forces between 90 and $99 \%$ of the $\mathrm{CO}_{2}$ out of solution. Previous studies performed in our lab indicate that healthy plants can be grown at a pH of 4.0 (Monje and Bugbee, 1998).

Relative humidity was maintained between $60 \%$ and $80 \%$.PPF was $600 \pm 30 \mu \mathrm{mol} \cdot \mathrm{m}^{-2} \cdot \mathrm{s}^{-1}( \pm 5 \%)$ to provide a daily integrated $P P F$ of $34.6 \mathrm{~mol} \cdot \mathrm{m}^{-2} \cdot \mathrm{d}^{-1}$. Chlorophyll content was estimated with a chlorophyll meter (model SPAD-502; Minolta). The SPAD values from the meter were converted to chlorophyll concentration (mg chlorophyll per $\mathrm{m}^{2}$ leaf) using the equation described in Monje and Bugbee (1992)

Ground cover fraction was measured every other day using a digital camera positioned directly above the canopies. Absorbed $P P F$ was also measured by measuring PPF incident, reflected, and transmitted through the canopy. The digital images were more accurate in estimating radiation capture when the lettuce seedlings were small and the line quantum sensor method was more accurate sume that $R_{d}$ occurs at the same rate as $R_{n}$ if the temperature is the same. $R_{d}$ was corrected using a $\mathrm{Q}_{10}$ exponential response function of respiration if the day/night temperature differed $\left(Q_{10}=1.2\right.$ for whole plant lettuce respiration during this growth phase, Frantz et al., 2003). $R_{d}$ would then be defined as $R_{n} \times$ (time in light)/(time in darkness), so for a 16-h photoperiod, $R_{d}=R_{n} \times 2$.In these equations, respiration assumes a positive value (i.e., mass respired).

Carbon use efficiency $(C U E)$ is a measure of how well the carbon that is fixed during the day remains in the plant, and was determined by $C U E=P_{\text {gross }} / D C G$, where $D C G$ is daily carbon gain and is determined by subtracting $R_{n}$ from $P_{n e t}: D C G=P_{n e t}-R_{n}$.

Studies With Light, CUlTIVAR, AND AERATION (STUdies 2 AND 3). Studies were performed with lettuce seedlings sown directly into $12.7 \times 12.7 \times 12.7$-cm pots. Pots were filled with a 1 peat : 1 perlite mixture and irrigated twice daily with nutrient solution. Soluble fertilizer (Peter's 5-11-26; Hydrosol) was combined with reagent grade $\mathrm{CaNO}_{3}$ and $\mathrm{Fe}-\mathrm{EDDHA}$ to give the following concentrations: $7.2 \mathrm{~mm} \mathrm{~N}, 0.75 \mathrm{~mm} \mathrm{P,} 2.7 \mathrm{~mm} \mathrm{~K}$, and $20 \mu \mathrm{M} \mathrm{Fe}$. We

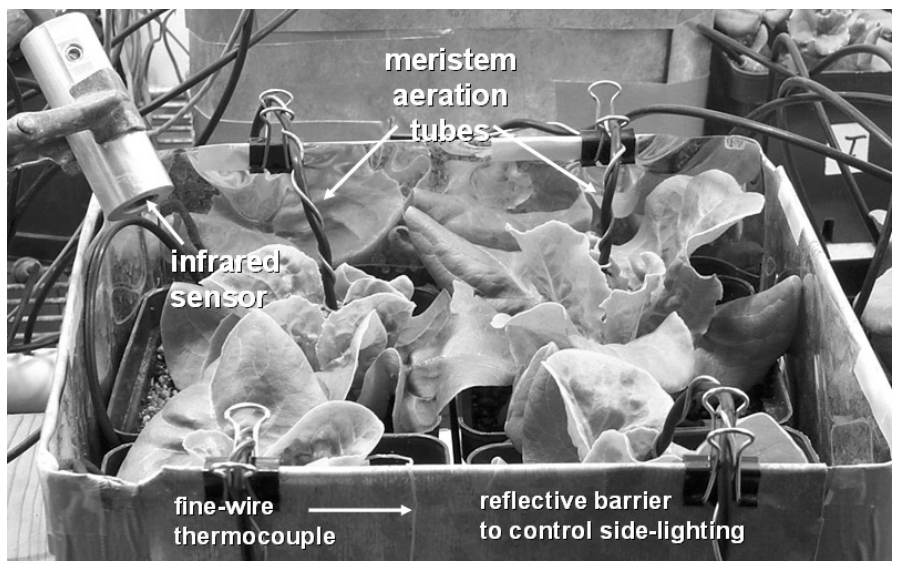

Fig. 2. A single canopy of Buttercrunch lettuce grown at a $P P F$ of $1000 \mu \mathrm{mol} \cdot \mathrm{m}^{-2} \cdot \mathrm{s}^{-1}$ with meristem aeration. The canopy has a reflective metal barrier to minimize side-lighting, an infrared sensor to measure leaf temperature, and a fine-wire thermocouple positioned on the underside of the leaf for additional monitoring of leaf temperature. Plants are $13 \mathrm{~d}$ old. 
sought to minimize $\mathrm{NH}_{4}$ in the nutrient solution to increase $\mathrm{Ca}^{2+}$ uptake. We found that technical (greenhouse) grade $\mathrm{CaNO}_{3}$ had significant contamination with $\mathrm{NH}_{4}{ }^{+}$, so we used reagent grade $\mathrm{CaNO}_{3}$. Our measurements indicated that Peter's Hydrosol has $\approx 2 \%$ of the $\mathrm{N}$ in the $\mathrm{NH}_{4}{ }^{+}$form, but the final concentration had $<1 \%$ of the $\mathrm{N}$ in the $\mathrm{NH}_{4}+$ form.

Seedlings were thinned $2 \mathrm{~d}$ after emergence to one plant per pot. Four pots were grouped together to form a canopy with a density of 69 plants $/ \mathrm{m}^{2}$ (Fig. 2). Four 10-cm fans were positioned in each corner to increase the wind speed to an average of $0.7 \pm 0.2 \mathrm{~m} \cdot \mathrm{s}^{-1}$ across the chamber measured $7-\mathrm{cm}$ above the plants. Based on the results of the temperature study (Study 1), air temperatures were maintained at $30 / 25^{\circ} \mathrm{C}$ to optimize leaf expansion and quantum yield. Temperatures were measured with two shielded, aspirated, type-E thermocouples in each chamber located at canopy height inside and outside the canopy. Leaf temperature was measured with a precision infrared sensor, which corrected for sensor body temperature (Fig. 2) (model IRT-P;Apogee Instruments Inc., Logan, Utah), and a fine-wire thermocouple positioned on the underside of a leaf. The infrared sensor was positioned 8 to $10 \mathrm{~cm}$ from a target leaf at a $60^{\circ}$ angle to minimize self shading. Relative humidity was controlled by activating a humidifier (model WF-225; Walton Laboratories, Union, N.J.) if the relative humidity dropped below $75 \%$ during the day or night based on a relative humidity sensor (model 50Y; Vaisala, Inc., Woburn, Mass.). One canopy of each cultivar in each chamber in Study 2, and two canopies of each cultivar in each chamber in Study 3 had air blown directly on the meristem ( $1 \mathrm{~L} \cdot \mathrm{min}^{-1}, 25 \%$ relative humidity). Our measurements indicated that this created a localized $(\approx 1 \mathrm{~cm})$, low humidity environment around the meristem.

In Study 2, a single reach-in chamber (model PT.80, Percival, Boone, Iowa) was maintained at a $P P F$ of $500 \pm 25 \mu \mathrm{mol} \cdot \mathrm{m}^{-2 \cdot} \cdot \mathrm{s}^{-1}$ and another chamber at $1000 \pm 50 \mu \mathrm{mol} \cdot \mathrm{m}^{-2} \cdot \mathrm{s}^{-1}$. There were two replicate canopies of four cultivars ('Tiber', 'Waldmann's Green', 'Grand Rapids' and 'Buttercrunch') in each chamber. Extent of tipburn severity was determined for each cultivar. Yield data was pooled across cultivars and analyzed with ANOVA and regression (SigmaStat, SPSS Science, Chicago, Ill.).

In Study 3, two canopies each of 'Waldmann's Green' and 'Buttercrunch' were grown in each of two replicate chambers. $P P F$ was $1000 \pm 50 \mu \mathrm{mol} \cdot \mathrm{m}^{-2} \cdot \mathrm{s}^{-1}$ measured at the top of the canopy. One chamber was harvested on day 19 (after seed imbibition) and the second chamber was harvested on day 28 . This allowed us to measure changes in final mass over the last few days of growth when the effects of tipburn would be greatest. Data were kept separate between cultivars and analyzed with ANOVA and regression.

Cultivar Selection. 'Grand Rapids' is a popularcultivar that has been widely used in lettuce research. 'Waldmann's Green' is similar to 'Grand Rapids' but it has darker green leaves. 'Buttercrunch' is a standard butterhead-type of lettuce with dark green leaves. We originally hypothesized that dark and light green varieties may respond differently to high light. 'Tiber' was used in a single trial because it had been bred specifically for tipburn resistance (Ryder and Waycott, 1998). Other studies in this lab indicated that all of these cultivars responded similarly to environmental conditions, except chlorophyll concentration response to temperature (see Results and Discussion).

TIPBURN InDEX. Lettuce was scored after $28 \mathrm{~d}$ for severity of tipburn using an index that accounted for both severity of tipburn and number of affected plants. Previous tipburn indices evaluated either tipburn severity or number of affected plants but not both (Misaghi et al., 1981b; Nagata and Stratton, 1994). As a result, a high score in those indices does not distinguish between all plants with minor tipburn or few plants with major tipburn. In this index, the following equation was used: $\{[(S \times 5)+(M \times 3)+(L \times 1)] \times$ $100\} / P \times 5$, where $S$ is the number of plants with severe tip burn, $M$ is the number of plants with medium tipburn, $L$ is the number of plants with light tipburn, and $P$ is the total number of plants. Severe tipburn is defined as the occurrence of malformed leaves and meristem death in $>80 \%$ of leaves. Medium tipburn exists when a few older leaves and the meristem have small necrotic spots and leaf margins appear blackened and misshapen. Light tipburn is indicated when only the central leaflets show very small necrotic spots. In this index, more emphasis is placed on severely affected plants, and less emphasis on the plants with only minor tipburn symptoms. A score of 100 would indicate that all plants have severe tipburn while a score of 20 may indicate all plants have only minor symptoms.

\section{Results and Discussion}

Temperature STUdy (STUdy 1). The three determinants of yield are summarized in Fig. 3A, C, and E. Successive multiplication of the three determinants indicates daily carbon gain (Fig. 3G). The lowest and highest average daily temperatures (21 and 33 ${ }^{\circ} \mathrm{C}$, respectively) had the lowest daily carbon gain per unit ground area (Fig. 3G and $\mathrm{H}$ ). The highest daily carbon gain was obtained in the treatments with average daily temperatures of 27 or $30^{\circ} \mathrm{C}$. Tipburn was observed at all temperatures, but was not quantified for severity in this study. There was a strong influence of temperature on leaf expansion (Fig. 3A). The 27 and $30{ }^{\circ} \mathrm{C}$ treatments both reached near maximum $P P F$ absorption by day 16 . Conversely, the canopy never closed in the $33^{\circ} \mathrm{C}$ treatment. Averaged over the 24 $\mathrm{d}$ after transplanting, the 27 and $30^{\circ} \mathrm{C}$ treatments had the highest daily $P P F$ absorbed (Fig. 3B). Canopy quantum yield increased with temperature, and did not change significantly over time (Fig. 3C and D).

All temperature treatments had similar $C U E$ of 0.62 after Day 9 (Fig. 3E). There was no effect of temperature on $C U E$ (Fig. 3F, slope $=0.0001)$. This finding is surprising given the widely accepted view that respiration increases exponentially in higher temperatures. The nearly identical $C U E$ across temperatures indicates that respiration and photosynthesis increase in exact proportion to each other in elevated temperatures in a high $\mathrm{CO}_{2}$ environment. These data suggest that lettuce may be equally efficient at both high and low temperatures at conserving carbon fixed during the day. Gifford (1995) also reported similar $C U E$ in a wide range of species and growth conditions in ambient $\mathrm{CO}_{2}$. Frantz et al. (2003) changed the night temperature in the middle of the life cycle and found small reductions in $C U E$. The change was caused by increased nighttime respiration, but the reduction in $C U E$ was not large enough to cause differences in growth.

Chlorophyll content in 'Grand Rapids' increased significantly with higher temperatures (Fig. 4). The highest temperature treatment had $\approx 10$-fold higher chlorophyll content than the lowest treatment. This effect is especially interesting considering the relatively high light $\left(600 \mu \mathrm{mol} \cdot \mathrm{m}^{-2 \cdot} \cdot \mathrm{s}^{-1}\right)$ in this study and the belief that high light in lettuce will result in photobleaching. Our results indicate that temperature primarily determines chlorophyll content for 'Grand Rapids' lettuce, but this effect may be unique to this cultivar since 'Waldmann's Green', 'Tiber', and 'Buttercrunch' chlorophyll concentrations were not different in different temperatures or light (data not shown).

Study With Cultivar, Aeration, AND light (STUdy 2). Sur- 


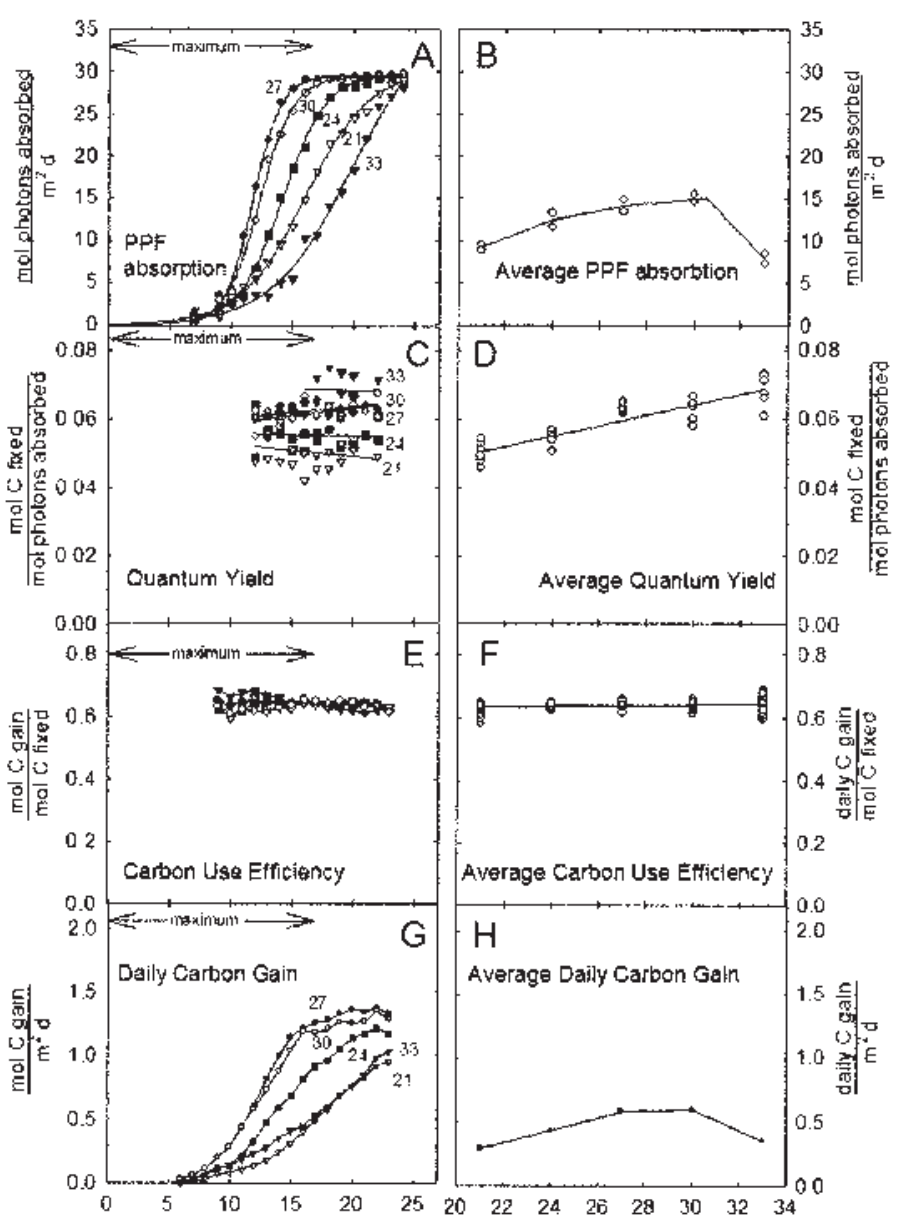

Fig. 3. The three determinants of yield expressed on both a time and a temperature basis for lettuce canopies grown in $1200 \mu \mathrm{mol} \cdot \mathrm{mol}^{-1} \mathrm{CO}_{2}$ Average day/night temperatures are shown. The arrows indicate the maximum reported literature value for each parameter. Carbon gain $(\mathbf{G}$ and $\mathbf{H})$ is calculated by successive multiplication of $P P F$ absorption (A and $\mathbf{B})$, quantum yield $(\mathbf{C}$ and $\mathbf{D})$, and carbon use efficiency ( $\mathbf{E}$ and $\mathbf{F})$. Grams per mole of photons can be calculated by multiplying moles of carbon by $12 \mathrm{~g} \cdot \mathrm{mol}^{-1}$ and dividing by 0.40 (the typical fraction of carbon in biomass). The maximum biomass yield per day was thus 42 $\mathrm{g} \cdot \mathrm{d}^{-1}$ out of a potential maximum of $63 \mathrm{~g} \cdot \mathrm{d}^{-1}$ for this $P P F\left(34.6 \mathrm{~mol} \cdot \mathrm{m}^{-2} \cdot \mathrm{d}^{-1}\right)$.

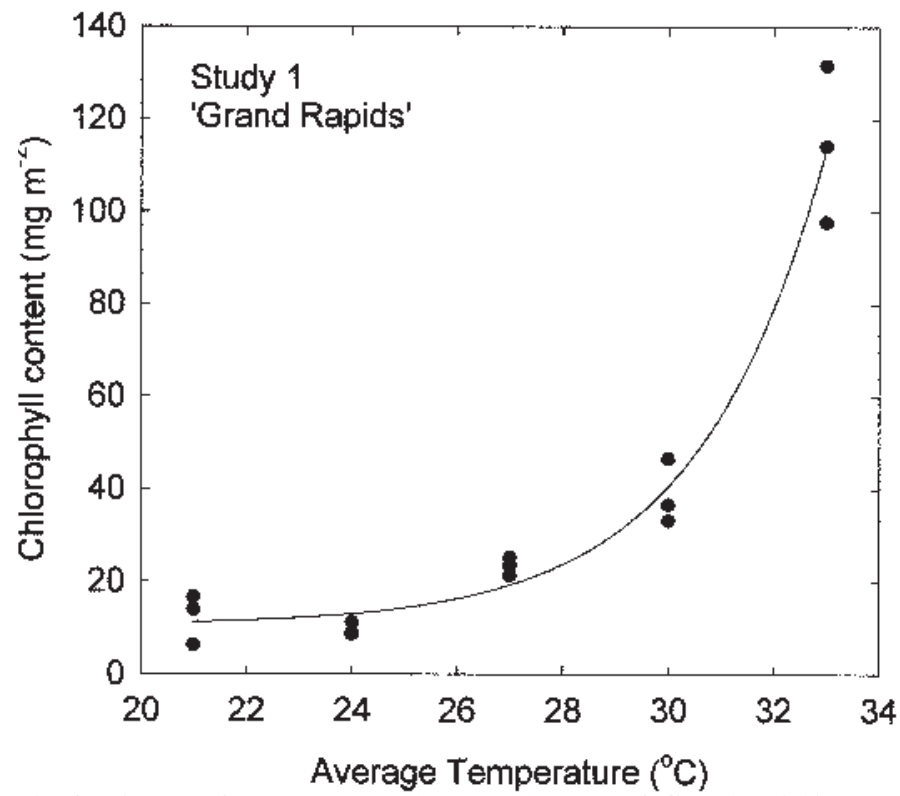

Fig. 4. Influence of temperature on chlorophyll content of 'Grand Rapids' on day 13. Plants were grown at a $P P F$ of $600 \mu \mathrm{mol} \cdot \mathrm{m}^{-2} \cdot \mathrm{s}^{-1}$. prisingly, the literature on lettuce response to high $P P F$ is not clear. Lettuce shoot dry weight might decrease under high $P P F$ (Tibbitts et al., 1983; Knight and Mitchell, 1983; Mitchell et al., 1991), or increase in high PPF (Mitchell et al., 1997; Knight and Mitchell, 1983; Knight and Mitchell, 1988; Guadreau et al., 1994). Decreased yield in high $P P F$ was speculated to have been caused by a combination of lamp type (HPS vs fluorescent + incandescent) and N-nutrition (Mitchell et al., 1991), or a species-specific (Tibbitts et al., 1983) or cultivar-specific (Knight and Mitchell, 1983) response of lettuce.

There was a linear yield response to increased $P P F$ up to 1000 $\mu \mathrm{mol} \cdot \mathrm{m}^{-2} \cdot \mathrm{s}^{-1}$ in canopies with meristem aeration (Fig. 5). This is a larger response to $P P F$ than any other high $P P F$ study (Mitchell et al., 1997; Knight and Mitchell, 1983; Knight and Mitchell, 1988; Guadreau et al., 1994). In those studies, tipburn increased with additional light (Gaudreau et al., 1994), PPF was not elevated until the final 10 d of growth (Mitchell et al., 1997; Knight and Mitchell, 1983; Knight and Mitchell, 1988) and lower temperatures were used, which likely affected leaf expansion and thus yield. Tipburn was not observed in our canopies that had meristem aeration, suggesting that the yield saturation in response to $P P F$ is due to tipburn, which reduces leaf expansion in the latter stages of growth (after canopy closure) when growth rate is maximal. The difference between the aerated and unaerated treatments was not statistically significant, however $(P=0.084)$. Experimental error was reduced in Study 3 and statistical power was increased by reducing the number of cultivars from four to two.

The high $P P F$ levels used in these studies could have resulted in significant heating of the leaves. However, there was a Plexiglass barrier below the lamps to reduce thermal radiation, and the plants were well watered, so the leaf temperature in all studies was 1 to $2{ }^{\circ} \mathrm{C}$ below the air temperature.

Tipburn began earlier in 'Buttercrunch' and was more severe than the three other cultivars. 'Tiber', a cultivar bred for tipburn resistance in the field, had the same tipburn sensitivity as 'Waldmann's Green' and 'Grand Rapids'. Selecting for tipburn resistance in the

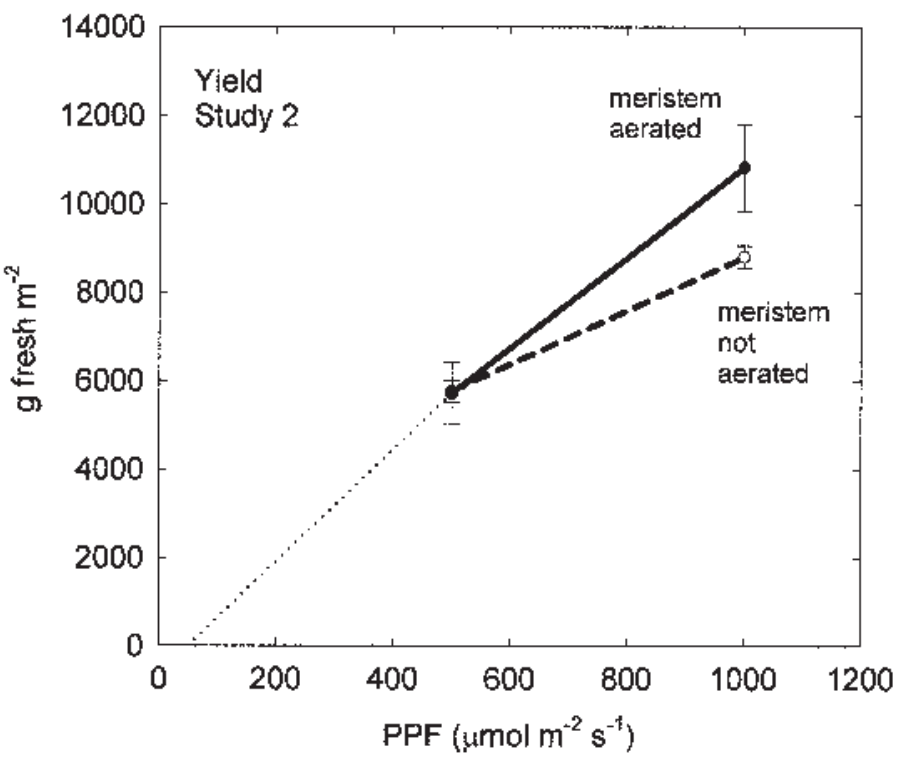

Fig. 5. Yield response, in grams fresh leaf biomass, of 'Waldmann's Green' and 'Buttercrunch' lettuce to high light with and without aeration on meristem in Study 2. The estimated light compensation point is shown at a PPF of 50 $\mu \mathrm{mol} \cdot \mathrm{m}^{-2} \cdot \mathrm{s}^{-1}$. Data were pooled between cultivars and error bars are \pm 1 standard error of the mean. $P$ value and n number suggest that the observed differences were marginally significant and would have been statistically significant $(P<$ 0.05 ) with additional power (larger $n$ number). 
Table 2. Extent of tipburn on 'Buttercrunch' and 'Waldmann's Green' lettuce cultivars in Study 3 with and without meristem aeration. The tipburn index takes into account both the number of plants with tipburn and the tipburn severity of each plant.

\begin{tabular}{lcc}
\hline Cultivar & Treatment & Tipburn index (\%) \\
\hline Buttercrunch & Meristem aeration & 5 \\
Waldmann's Green & Control & 95 \\
& & \\
& Meristem aeration & 0 \\
& Control & 60 \\
\hline
\end{tabular}

field may not confer tipburn resistance for rapid growth rates in controlled environments.

Study with CUltivar and aeration (STUdy 3). Meristem aeration eliminated tipburn in 'Waldmann's Green' and almost eliminated it in 'Buttercrunch' (Table 2, Fig. 6A-D). This finding confirms earlier work that introduced the concept of aerating meristems to reduce tipburn (Goto and Takakura, 1992a; Goto and Takakura, 1992b). However, the original studies used a PPF of only 180 to $230 \mu \mathrm{mol} \cdot \mathrm{m}^{-2} \cdot \mathrm{s}^{-1}$ and we eliminated tipburn at extremely high $P P F\left(1000 \mu \mathrm{mol} \cdot \mathrm{m}^{-2} \cdot \mathrm{s}^{-1}\right)$. Without aeration, tipburn symptoms initially appeared on about day 14 for 'Buttercrunch' and about day 16 for 'Waldmann's Green'. This is consistent with Study 2 and suggests that 'Waldmann's Green' is more resistant to tipburn than 'Buttercrunch'. Bres and Weston (1992) also reported that 'Waldmann's Green' was more resistant to tipburn than some other cultivars.

There was no difference in fresh mass between the aerated and unaerated treatments of either cultivar at the first harvest (Fig. 7A). Over the next $9 \mathrm{~d}$, however, the fresh mass of both treatments increased significantly with a larger increase in the aerated treatments. All aerated treatments had significantly higher fresh mass than the unaerated canopies. There were no differences between cultivars.

There were no differences in percent dry matter at the first harvest (Fig. 7B). At the second harvest, however, all unaerated canopies had significantly higher percent dry matter. This finding confirmed our observations during harvest that the aerated canopies were more succulent and fragile. As a result of differences in percent dry matter, the final dry mass for both cultivars in each treatment were similar (Fig. 7C). This was surprising because we expected that reduced tipburn would increase leaf expansion for late-forming leaves and thus increase dry mass. We also expected growth rate to decrease once tipburn began in the unaerated controls. Furthermore, we did not expect differences in percent dry matter between the treatments.

Canopy closure occurred on day 16 for both 'Buttercrunch' and 'Waldmann's Green' in both aerated and unaerated canopies. When canopy closure occurs in lettuce, $\approx 80 \%$ of $P P F$ is absorbed (Klassen et al., 2003). Aeration may have increased leaf expansion, but $P P F$ absorption was already close to the maximum when tipburn began. Therefore, an increase in the duration of leaf expansion would not necessarily increase light capture. Aeration may increase dry mass in single spaced plants because exterior leaves would not be constrained by adjacent plants, so interior leaves could expand and play a larger role in carbon gain. Aeration would likely be more important in longer studies since tipburn would continue to increase in unaerated plants. Meristem aeration may not have improved productivity as we expected because dry air $(25 \% \mathrm{RH})$ was used. It is possible that aerating with more humid air would have increased transpiration enough to eliminate tipburn without reducing the water potential of meristematic cells. This was not tested in this study,

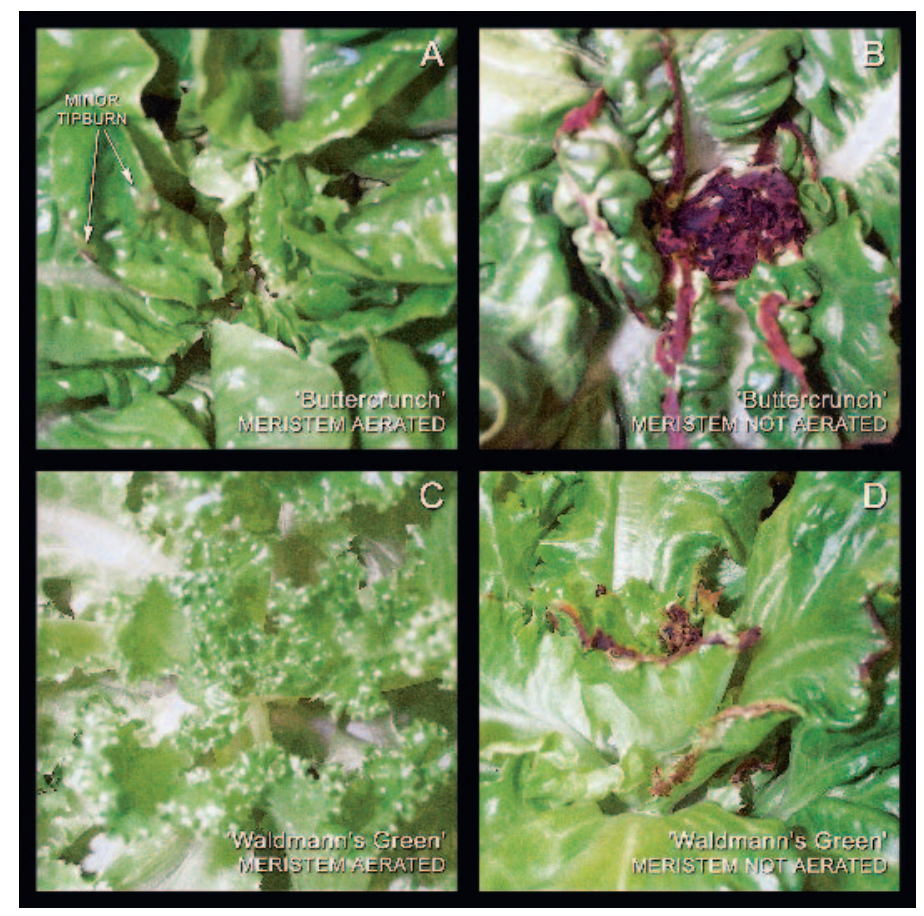

Fig. 6. 'Buttercrunch' plants with (A) and without (B) aeration of the meristem and 'Waldmann's Green' with $(\mathbf{C})$ and without $(\mathbf{D})$ meristem aeration. Tipburn was almost eliminated in the aerated 'Buttercrunch' plants, but a few small spots were observed on one of the plants. No such spots were observed on any of the 'Waldmann's Green' plants, so aeration eliminated tipburn in this cultivar.

but our measurements indicated that the low humidity zone was localized within a 1-cm radius around the meristem.

The carbon fixed late in growth was partitioned differently in the two treatments (Fig. 8A). Mature leaves in unaerated treatments were still green and presumed functional at the end of the study, and could accumulate mass regardless of tipburn on young leaves. The aerated canopies had a higher specific leaf area than unaerated canopies so aeration maintained their ability to make thinner leaves for more efficient light capture. The shoot harvest index (SHI) decreased across time in both treatments, but the decrease was larger in the unaerated controls (Fig. 8B). Since all leaf mass was counted as edible, the differences in $S H I$ were a result of greater stem mass in unaerated controls.

The treatments differed greatly in quality. Aerated plants had minimal tipburn and good quality. All unaerated 'Buttercrunch' plants had severe tipburn with both interior and exterior malformed leaves, blackened meristem, and shorter, misshapen heads. Unaerated 'Waldmann's Green' had less severe tipburn than unaerated 'Buttercrunch'. Only the interior leaves were blackened and no exterior leaves showed symptoms of tipburn. Because of the extent of tipburn, none of the 'Buttercrunch' leaves and only $\approx 2 / 3$ of the 'Waldmann's Green' leaves would be considered 'edible'. Meristem aeration can thus greatly increase edible yield by eliminating tipburn.

Lettuce productivity increased with higher light and temperature when tipburn was eliminated. Meristem aeration may not be practical for some production facilities, but Shibata et al. (1995) reported reduced tipburn and a $30 \%$ increase in yield in a controlled environment lettuce production facility when air was blown down vertically onto the plants. It may be practical to aerate meristems to maximize yields in intensive lettuce culture such as Advanced Life Support Systems for NASA or in so-called indoor lettuce factories.

Most of the literature on lettuce productivity has analyzed the 


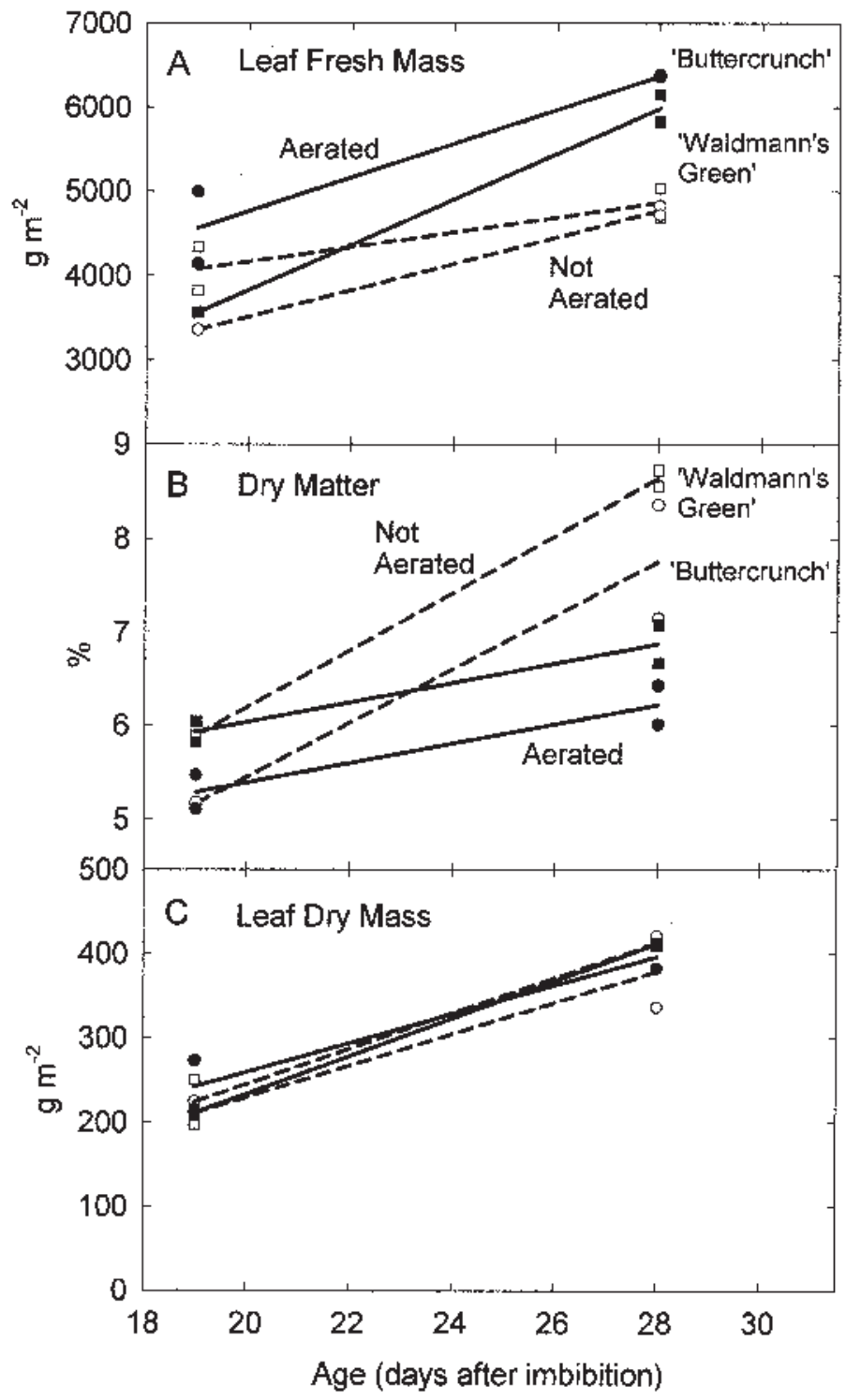

Fig. 7. Leaf fresh mass (A), percent dry matter of the leaf (B), and leaf dry mass (C) in 'Buttercrunch' and 'Waldmann's Green' with and without aeration in Study 3. Most of the aeration effect occurred during the final week of growth.

growth rate and final biomass of single well-spaced plants. Measuring the yield of single plants avoids the complications of minimizing side lighting in a small plot, but single plant yields cannot easily be extrapolated to production systems where plants are grown at higher densities to optimize yield per unit area. The plants in this study were grown at a density of 106 plants $/ \mathrm{m}^{2}$ (10.3-cm spacing). This planting density is a compromise between the higher yield per unit area that could be achieved with increased plant density and the higher biomass per plant that would occur with reduced plant density. The beneficial effects of meristem aeration should be independent of the planting density.

Some progress has been made in breeding. Several tipburn resistant cultivars have been developed for the field, and these cultivars should be tested in controlled environments. As evidenced by 'Tiber', tipburn severity in the field is not sufficient to select for resistance in controlled environments. Our lack of understanding of the exact environmental causes of tipburn and how differences between field and controlled environments may exacerbate tipburn also makes it difficult to extrapolate from the field to the chamber and vice versa. For example, Tibbitts et al. (1985) clearly assign a role of laticifer rupture as a cause of tipburn. Laticifer rupture

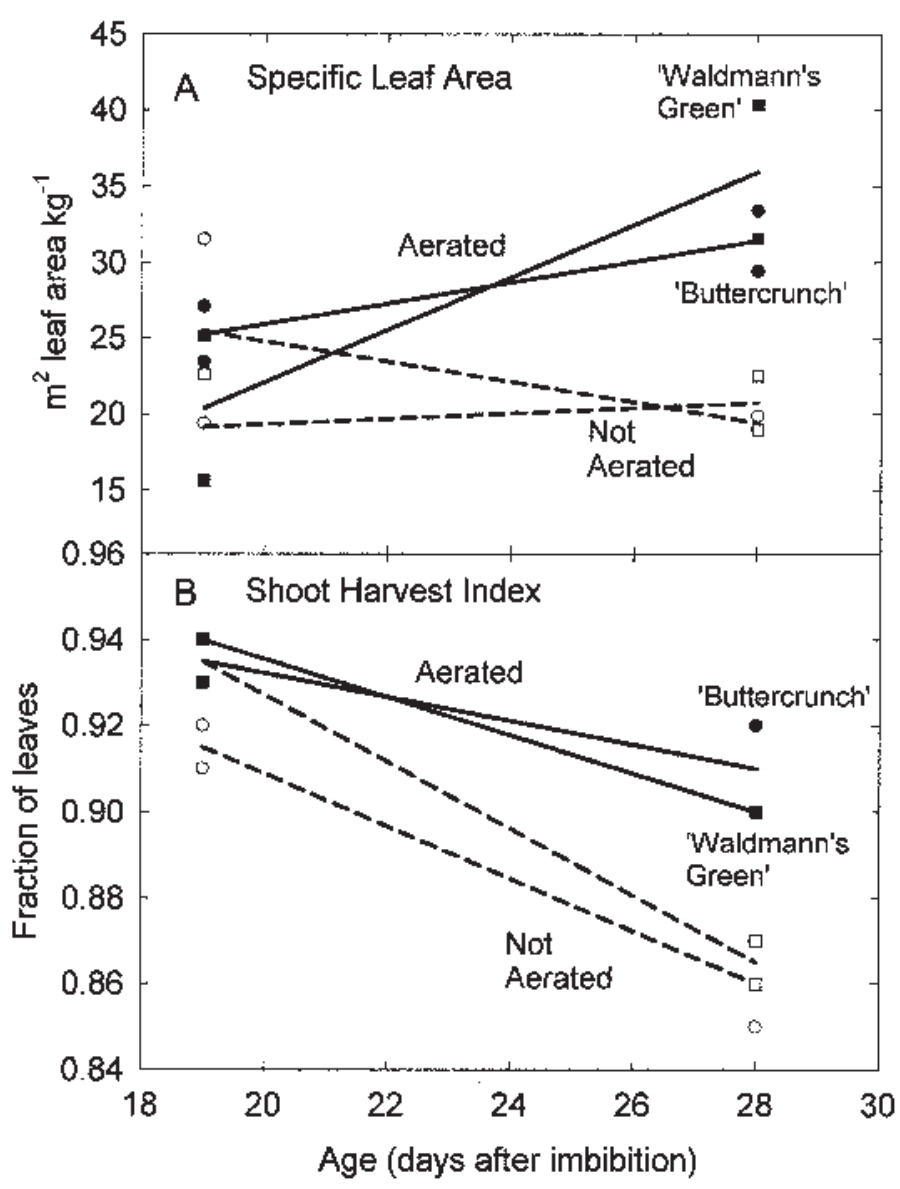

Fig. 8. Effect of age and aeration on specific leaf area (A) and shoot harvest index (B) in 'Buttercrunch' and 'Waldmann's Green' in Study 3 . All leaves, regardless of their tipburn index were counted as edible for this analysis.

and a force/resistance model, as described by Collier and Tibbitts (1982), explains why tipburn incidence begins in early morning in both field and chamber studies (when turgor pressure is highest) and why aeration of the meristem helps eliminate tipburn (increases cell wall strength by supplying $\mathrm{Ca}^{2+}$ to low-Ca areas). The force/ resistance model deserves further study, especially considering the gradual diurnal environmental changes in the field may cause less tipburn than the sudden temperature and light changes typical of controlled environments.

\section{Literature Cited}

Atkin, O.K., J.R. Evans, M.C. Ball, H. Lambers, and T.L. Pons. 2000. Leaf respiration of snow gum in the light and dark. Interactions between temperature and irradiance. Plant Physiol. 122:915-923.

Amthor, J.S. 1989. Respiration and crop productivity. Springer-Verlag, New York.

Azcón-Bieto, J. and C.B. Osmond. 1983. Relationship between photosynthesis and respiration. The effect of carbohydrate status on the rate of $\mathrm{CO}_{2}$ production by respiration in darkened and illuminated wheat leaves. Plant Physiol. 71:574-581.

Barta, D.J. 1989. Determination of low calcium concentrations across developing leaves of lettuce: implications for tipburn development. PhD diss. Univ. Wis.Madison.

Barta, D.J. and T.W. Tibbitts. 1986. Effects of artificial enclosure of young lettuce leaves on tipburn incidence and leaf calcium concentration. J. Amer. Soc. Hort. Sci. 111:413-416.

Barta, D.J. and T.W. Tibbitts. 1991. Calcium localization in lettuce leaves with and without tipburn: Comparison of controlled-environment and field-grown plants. J. Amer. Soc. Hort. Sci. 116:870-875.

Barta, D.J. and T.W. Tibbitts. 2000. Calcium localization and tipburn development in lettuce leaves during early enlargement. J. Amer. Soc. Hort. Sci. 125:294-298.

Bradfield, E.G. and C.G. Guttridge. 1984. Effects of salt concentration and cation balance in soils on leaf tipburn and calcium content of strawberry leaves and 
fruit. Commun. Soil Sci. Plant Anal. 15:681-693.

Bres, W. and L.A. Weston. 1992. Nutrient accumulation and tipburn in NFT-grown lettuce at several potassium and pH levels. HortScience 27:790-792.

Bugbee, B.G. and F.B. Salisbury. 1988. Exploring the limits of crop productivity I. Photosynthetic efficiency of wheat in high irradiance environments. Plant Physiol. 88:869-878.

Bugbee, B., B. Spanarkel, S. Johnson, O. Monje, and G. Koerner. 1994. $\mathrm{CO}_{2}$ crop growth enhancement and toxicity in wheat and rice. Adv. Space Res. 14: 257-267.

Clifton-Brown, J.C. and M.B. Jones. 1997. The thermal response of leaf extension rate in genotypes of the $\mathrm{C} 4$-grass Miscanthus: an important factor in determining the potential productivity of different genotypes. J. Expt. Bot. 48:1573-1581.

Collier, G.F. and T.W. Tibbitts. 1982. Tipburn of lettuce. Hort Rev. 4:49-65.

Collier, G.F. and T.W. Tibbitts. 1984. Effects of relative humidity and root temperature on calcium concentration and tipburn development in lettuce. J. Amer. Soc. Hort. Sci. 109:128-131.

Collier, G.F. and D.C.E. Wurr. 1981. The relationship of tipburn incidence in head lettuce to evaporative water loss and leaf dimensions. J. Hort. Sci. 56:9-13.

Cubeta, M.A., B.R. Cody, R.E. Sugg, and C.R. Crozier. 2000. Influence of soil calcium, potassium, and $\mathrm{pH}$ on development of leaf tipburn of cabbage in eastern North Carolina. Commun. Soil Sci. Plant Anal. 31:259-275.

Dougher, T.A. O. andB. Bugbee. 2001. Differences in the response of wheat, soybean, and lettuce to reduced blue radiation. Photochem. Photobio. 73:199-207.

Farquhar, G.D., S. von Caemmerer, and J.A. Berry. 1980. A biochemical model of photosynthetic assimilation in leaves of C3 species. Planta 149:78-90.

Faust, J.E. and R.D. Heins. 1994. Modeling inflorescence development of the African violet (Saintpaulina ionantha Wendl.). J. Am. Soc. Hort. Sci. 119:727-734.

Feigin, A., E. Pressman, P. Imas, and O. Miltau. 1991. Combined effects of KNO3 and salinity on yield and chemical composition of lettuce and Chinese cabbage. Irrig. Sci. 12:223-230

Frantz, J.M., N.N. Cometti, and B. Bugbee. 2003. Night temperature has a minimal effect on growth and respiration in rapidly growing plants. 21 July 2003 www.usu.edu/cpl.

Gaudreau, L., J. Charbonneau, L. Vezina, and A. Gosselin. 1994. Photoperiod and photosynthetic flux influence growth and quality of greenhouse-grown lettuce. HortScience 29:1285-1289.

Gifford, R.M. 1995. Whole plant respiration and photosynthesis of wheat under increased $\mathrm{CO}_{2}$ concentration and temperature: long-term vs. short-term distinctions for modeling. Global Change Biol. 1:385-396.

Goto, E. and T. Takakura. 1992a. Prevention of lettuce tipburn by supplying air to inner leaves. Trans. Amer. Soc. Agr. Eng. 35:641-645

Goto, E. and T. Takakura. 1992b. Promotion of Ca accumulation in inner leaves by air supply for prevention of lettuce tipburn. Trans. Amer. Soc. Agr. Eng. 35: $647-650$.

Hammer, P.A., T.W. Tibbitts, R.W. Langhans, and J.C. McFarlane. 1978. Base-line growth studies of 'Grand Rapids' lettuce in controlled environments. J. Amer. Soc. Hort. Sci. 103:649-655.

Harley, P.C. and J.D. Tenhunen. 1991. Modeling the photosynthetic response of C3 leaves to environmental factors. Modeling crop photosynthesis - From biochemistry to canopy. CSSA Spec. Publ. 19.

Ho, L.C., R. Belda, M. Brown, J. Andrews, and P. Adams. 1993. Uptake and transport of calcium and the possible causes of blossom-end rot in tomato. J. Expt. Bot. 44:509-518.

Jie, H. and L.S. Kong. 1997. Growth and photosynthetic responses of three aeroponically grown lettuce cultivars (Latuca sativa L. to different rootzone temperatures and growth irradiances under tropical aerial conditions. J. Hort. Sci. Biotech. 73:173-180.

Klassen, S.P., G. Ritchie, J.M. Frantz, D. Pinnock, and B. Bugbee. 2003. Realtime imaging of ground cover: relationships with radiation capture, canopy photosynthesis, and daily growth rate, p. 1-12. In: Digital imaging and spectral techniques: applications to precision agriculture and crop physiology. Amer. Soc. Agron. Spec. Publ. 66. Madison, Wis.

Knight, S.L. and C.A. Mitchell. 1983. Enhancement of lettuce yield by manipulating of light and nitrogen nutrition. J. Amer. Soc. Hort. Sci. 108:750-754.

Knight, S.L. and C.A. Mitchell. 1988. Effects of $\mathrm{CO}_{2}$ and photosynthetic photon flux on yield, gas exchange, and growth rate of Latuca sativa L. 'Waldmann's Green'. J. Expt. Bot. 39:317-328.

Koontz, H.V. and R.P. Prince. 1986. Effect of 16 and 24 hours daily radiation (light) on lettuce growth. HortScience 21:123-124.
Lal, A. and G.E. Edwards. 1995. Maximum quantum yields of $\mathrm{O}_{2}$ evolution in $\mathrm{C} 4$ plants under high $\mathrm{CO}_{2}$. Plant Cell Physiol. 36:1311-1317.

Long, S.P. 1991. Modification of the response of photosynthetic productivity to rising temperature by atmospheric $\mathrm{CO}_{2}$ concentrations: Has its importance been underestimated? Plant Cell Environ. 14:729-739.

Marschner, H. 1995. Mineral Nutrition of Higher Plants. 2nd ed. Academic Press, London.

Misaghi, I.J., C.A. Matyac, and R. G. Grogan. 1981a. Soil and foliar applications of calcium chloride and calcium nitrate to control tipburn of head lettuce. Plant Dis. 65:821-822.

Misaghi, I.J., R.G. Grogan, and F. V. Westerlund. 1981b. A laboratory method to evaluate lettuce cultivars for tipburn tolerance. Plant Dis. 65:342:344.

Misaghi, I.J. and R.G. Grogan. 1978. Effect of temperature on tipburn development in head lettuce. Ecol. Epidemiol. 32:1738-1743.

Mitchell, C.A., C. Chun, W.E. Brandt, and S.S. Nielsen. 1997. Environmental modification of yield and nutrient composition of 'Waldmann's Green' leaf lettuce. J. Food. Qual. 20:73-80.

Mitchell, C.A., T. Leakakos, and T.L. Ford. 1991. Modification of yield and chlorophyll content in leaf lettuce by HPS radiation and nitrogen treatments. HortScience 26:1371-1374.

Monje, O. and B. Bugbee. 1992. Inherent limitations of nondestructive chlorophyll meters: A comparison of two types of meters. HortScience 27:69-71.

Monje, O. and B. Bugbee. 1998. Adaptation to high $\mathrm{CO}_{2}$ concentration in an optimal environment: radiation capture, canopy quantum yield, and carbon use efficiency. Plant Cell Environ. 21:315-324.

Morard, P., L. Lacoste, and J. Silvestre. 2000. Effects of calcium deficiency on nutrient concentration of xylem sap of excised tomato plants. J. Plant Nut. 23: 1051-1062.

Mostafa, M.A.E. and A. Ulrich. 1976. Absorption, distribution, and form of Ca in relation to Ca deficiency (tip burn) of sugarbeets. Crop Sci. 16:27-30.

Nagata, R. T. and M. L. Stratton. 1994. Development of an objective test for tipburn evaluation. Proc. Fla. State Hort. Soc. 107:99-101.

Olesen, J. E. and K. Grevsen. 1997. Effects of temperature and irradiance on vegetative growth of cauliflower (Brassica oleracea L. botrytis) and broccoli (Brassica oleracea L. italica). J. Expt. Bot. 48:1591-1598.

Pollan, M. 2002. The botany of desire: A plant's eye view of the world. Random House, New York.

Reddy, K. R., H. F. Hodges, and J. M. McKinion. 1993. Temperature effects on Pima cotton leaf growth. Agron. J. 85:681-686.

Rosen, C.J. 1990. Leaf tipburn in cauliflower as affected by cultivar, calcium sprays, and nitrogen nutrition. HortScience 25:660-663.

Ryder, E.J. and W. Waycott. 1998. Crisphead lettuce resistant to tipburn: cultivar Tiber and eight breeding lines. HortScience 33:903-904.

Saure, M.C. 1998. Causes of the tipburn disorder in leaves of vegetables. Scientia Hort. 76:131-147.

Sharp, R.E., M.A. Matthews, and J.S. Boyer. 1984. Kok effect and the quantum yield of photosynthesis. Light partially inhibits dark respiration. Plant Physiol. 75:95-101.

Shibata, T., K. Iwao, and T. Takano. 1995. Effect of vertical air flowing on lettuce growing in a plant factory. Acta Hort. 399:175-183.

Swiader, J.M., G.W. Ware, and J.P. McCollum. 1992. Producing vegetable crops. $4^{\text {th }}$ ed. Interstate Publ., Danville, Ill.

Tibbitts, T.W., D.C. Morgan, and I.J. Warrington. 1983. Growth of lettuce, spinach, mustard, and wheat plants under four combinations of high-pressure sodium, metal halide, and tungsten halogen lamps at equal PPFD. J. Amer. Soc. Hort. Sci. 108:622-630

Tibbitts, T.W., J. Bensink, F. Kuiper, and J. Hobé. 1985. Association of latex pressure with tipburn injury of lettuce. J. Amer. Soc. Hort. Sci. 110:362-365.

van Iersel, M.W. and B. Bugbee. 2000. A multiple chamber, semicontinuous, crop carbon dioxide exchange system: Design, calibration, and data interpretation. J. Amer. Soc. Hort. Sci. 125:86-92.

Volk, T, R. Wheeler, and B. Bugbee. 1995. An approach to crop modeling with the energy cascade. Life Support Biosphere Sci. 1:119-127.

Welch, J.E., G.M. Kihara, and K.A. Kimble. 1983. 'Alamo', 'Anza', 'Calrey', 'Calrico', 'Laguna', 'Ramona', 'Rita', 'Vega', and 'Vista' crisphead lettuce. HortScience 18:489-492.

Yanagi, A.A., R.M. Bullock, and J.J. Cho. 1983. Factors involved in the development of tipburn in crisphead lettuce in Hawaii. J. Amer. Soc. Hort. Sci. 108: 234-237. 